\title{
Comparison of Two Methods for the Extraction of Fractionated Rice Bran Protein
}

\author{
Changyuan Wang, ${ }^{1,2}$ Dan Li, ${ }^{2}$ Feng Xu, ${ }^{2}$ Tianshu Hao, ${ }^{2}$ and Min Zhang ${ }^{1,3}$ \\ ${ }^{1}$ College of Food Science, Northeast Agricultural University, Harbin, Heilongjiang 150-030, China \\ ${ }^{2}$ College of Food Science, Heilongjiang Bayi Agricultural University, Daqing, Heilongjiang 163-319, China \\ ${ }^{3}$ College of Food Science, Beijing Technology and Business University, 33 Fucheng Road, Beijing 100-037, China
}

Correspondence should be addressed to Min Zhang; zhangminneau@126.com

Received 13 June 2014; Accepted 4 September 2014; Published 15 October 2014

Academic Editor: Murat Senturk

Copyright (C) 2014 Changyuan Wang et al. This is an open access article distributed under the Creative Commons Attribution License, which permits unrestricted use, distribution, and reproduction in any medium, provided the original work is properly cited.

\begin{abstract}
Two different methods for extracting fractionated rice bran protein (FRBP) from defatted rice bran were investigated according to the solubility of protein in different extraction solvents. The yields of the obtained proteins and their purity were first compared. Sodium dodecyl sulfate polyacrylamide gel electrophoresis, differential scanning calorimetry, protein surface hydrophobicity, and protein secondary molecular structure analyses were subsequently applied to identify and compare the compositional, structural, and functional characteristics of the obtained proteins. The highest yield (13.8\%, w/w) and purity (45-47\%) of FRBP products were obtained using $0.4 \mathrm{M} \mathrm{NaCl}, 80 \%$ ethanol, and $0.01 \mathrm{M} \mathrm{NaOH}$ as extraction solvents to fractionate albumin, globulin, prolamin, and glutelin. Several good properties were exhibited, including good functionality, specific denaturation temperature, and enthalpy values, for FRBP products prepared by the above method.
\end{abstract}

\section{Introduction}

Cereals are the major source of dietary protein for a large population. The intake of rice protein exceeds other cereal protein, such as wheat protein and maize protein. Moreover, rice protein is hypoallergenic and rich in lysine. Thus, rice protein is widely used in infant foods and the formulation of restricted recipes for children with food allergies [1]. Compared with casein and soy isolate protein, the amino acid profile of rice protein satisfies the demands of 2- to 5-year-old children [2].

Economical and affordable protein is increasingly expected with the growing demands for foods. Various proteins from vegetable sources have been studied for a long time [3-6], which has led to an increase in inexpensive and nutritious foods.

Rice bran is a byproduct in milling unpolished rice, which contains $15.4 \%$ crude protein [7]. There is as much as 13.6 million tons of rice bran produced in China. Rice bran protein, which is extracted from defatted rice bran, can be added in various foods as a nourishing ingredient [8].
Thus, rice bran is a type of high value-added raw material that shows great potential in food applications. Although the availability and nutrition values of rice bran have been widely accepted, it is difficult to separate rice bran protein due to its association with phytate acid and cellulose [9]. Moreover, the solubility of rice bran protein is undesirable due to the high number of disulphide groups. At present, rice bran, which is mainly used for producing animal feeds, is insufficiently utilized [8].

Previous studies have reported that a number of approaches to extract fractionated rice bran protein (FRBP) from defatted rice bran are based on the solubility of FRBP in water, salt solution, alkaline, or weak acid/alcohol [10]. The methods including alkaline extraction are followed by isoelectric precipitation [11], and the methods use water, $50 \mathrm{~g} / \mathrm{kg} \mathrm{NaCl}, 60 \%$ alcohol, and $4 \mathrm{~g} / \mathrm{kg} \mathrm{NaOH}$ as the combined extraction solvent [12]. Despite the extensive efforts of researchers, the extraction approach for satisfactory fractionation of rice bran protein while maintaining its functionality is yet to be established. In this study, two FRBP extraction methods were compared, and the optimum 
method was selected based on the functionality of the obtained FRBP products.

\section{Materials and Methods}

2.1. Materials. Full-fat rice bran (Kongyu 131 variety) was obtained from Chahayang Farm, Nongkenzongju, Heilongjiang province, China. The defatted rice bran was prepared with the following procedures: full-fat rice bran was extracted with a 10-fold volume of hexane for $4 \mathrm{hr}$ and centrifuged at 4,000 r/min for $10 \mathrm{~min}$; the supernatant was collected; the hexane was removed by rotary evaporation; the remaining hexane was further removed in draught cupboard; and the obtained defatted rice bran was stored in a refrigerator at $4^{\circ} \mathrm{C}$.

\subsection{Methods}

\subsubsection{Extraction Methods}

Method 1. The protein extraction was performed at room temperature. Defatted rice bran (100 g) was mixed with $500 \mathrm{~mL}$ of distilled water for $1 \mathrm{~h}$ using a magnetic stirring apparatus followed by centrifugation at 4,500 r/min for $15 \mathrm{~min}$. The precipitate was extracted following the procedures as described above. Each supernatant was collected and filtered to obtain the albumin extract. The residue was subsequently extracted with $1 \mathrm{M} \mathrm{NaCl}$ following the procedure as described above to obtain the globulin extract. After removing albumin and globulin, the residue was extracted with $80 \%$ alcohol, and the prolamin fraction was obtained as freeze-dried precipitate by adding a 3-fold volume of acetone and centrifuging at $4,500 \mathrm{r} / \mathrm{min}$ for $15 \mathrm{~min}$. After removing albumin, globulin, and prolamin, the residue was extracted with $500 \mathrm{~mL}$ of $0.01 \mathrm{M} \mathrm{NaOH}$ according to the procedures described for the extraction of albumin to obtain the glutelin extract.

The albumin, globulin, and glutelin fractions were obtained by adjusting the $\mathrm{pH}$ of the extracts to their isoelectric points of 4.1,4.3, and 4.8, respectively. The precipitates were allowed to rest for $1 \mathrm{~h}$. The precipitated proteins were centrifuged at 4,500 r/min for $15 \mathrm{~min}$ and washed twice using distilled water by centrifugation, and the $\mathrm{pH}$ was neutralized before freeze-drying.

Method 2. The protein extraction was performed at room temperature. Defatted rice bran $(100 \mathrm{~g})$ was mixed with $500 \mathrm{~mL}$ of different extraction solvents for $1 \mathrm{~h}$ using a magnetic stirring apparatus. The sequence of the extraction solvents was as follows: $0.4 \mathrm{M} \mathrm{NaCl}, 80 \%$ alcohol and $0.01 \mathrm{MNaOH}$. The extract was kept separately, and the residue was reextracted. Each extraction step was followed by centrifugation at $4,500 \mathrm{r} / \mathrm{min}$ for $15 \mathrm{~min}$. The sequential extraction step was repeated on the residue with $400 \mathrm{~mL}$ of each extracting solution. Each extraction was combined and filtered.

The $0.4 \mathrm{M} \mathrm{NaCl}$ filtrate was dialyzed against water for $72 \mathrm{~h}$ at $4^{\circ} \mathrm{C}$ and then centrifuged at $4,500 \mathrm{r} / \mathrm{min}$ for $15 \mathrm{~min}$. The albumin and globulin fractions were collected from the supernatant and precipitate, respectively. Each of the fractions was separately freeze-dried.

The solvent in the $80 \%$ alcohol filtrate containing prolamin was removed using a rotary evaporator at $45^{\circ} \mathrm{C}$. The prolamin concentrate was extracted with hexane and then freeze-dried to obtain the prolamin fraction.

The $\mathrm{pH}$ of the $0.01 \mathrm{M} \mathrm{NaOH}$ filtrate was adjusted to 4.8 , and the glutelin fraction was then obtained. The precipitate was allowed to rest for $1 \mathrm{~h}$. The precipitated protein was centrifuged at 4,500 r/min for $15 \mathrm{~min}$ and washed twice with distilled water by centrifugation, and the $\mathrm{pH}$ was neutralized before freeze-drying.

2.2.2. Sodium Dodecyl Sulfate Polyacrylamide Gel Electrophoresis (SDS-PAGE) Analysis. SDS-PAGE analysis was performed on the FRBP products obtained by the two extraction methods. The analysis was performed using a SDSTris-glycine buffer system with 5\% (w/w) stacking gels and $12 \%(w / w)$ resolving gels following the method of Laemmli [13]. Electrophoresis was initially performed at a constant voltage of $80 \mathrm{~V}$ followed by an increase to $100 \mathrm{~V}$. At the end of electrophoresis, the gel was separated. The peptide and protein bands were stained with Coomassie brilliant blue G-250 for $6 \mathrm{~h}$ and destained with a solution composed of $5 \%$ ethanol, $10 \%$ acetic acid, and $85 \%$ distilled water. The gel images were scanned using an Alphalmager HP scanner (Proteinsimple, USA) and then subjected to analysis.

2.2.3. Protein Solubility. The FRBP sample $(0.5 \mathrm{~g})$ was dispersed in $20 \mathrm{~mL}$ of distilled water using a magnetic stirring apparatus and then diluted to a final volume of $25 \mathrm{~mL}$. The dispersion $(4 \mathrm{~mL})$ was added to a $15 \mathrm{~mL}$ centrifuge tube and centrifuged at 4,000 r/min for $10 \mathrm{~min}$. The protein concentration of the supernatant was measured by Lowry's method [14]. Absorbance was measured at $500 \mathrm{~nm}$, and a 5-point standard curve was established using bovine serum albumin (BSA; >98\% pure, Sigma, US). The protein solubility (expressed by dissolved nitrogen index, NSI) was calculated with (1) as follows:

$$
\begin{aligned}
& \text { NSI }(\%) \\
& =\frac{\text { Protein concentration in supernatant }}{\text { Protein concentration in FRBP dispersion }} \times 100 \text {. }
\end{aligned}
$$

2.2.4. Evaluation of Emulsifying Properties. The emulsifying properties of the FRBP products obtained by the two methods were evaluated by the turbidimetric method. To prepare the emulsion, $150 \mathrm{~mL}$ of FRBP solution and $50 \mathrm{~mL}$ of soy oil were homogenized with an Ultraturrax device (T-25, S25N10G, IKA Labortechnik, Karlsruhe, Germany) at 12,000 r/min for $1 \mathrm{~min}$. Aliquots $(50 \mu \mathrm{L})$ of freshly prepared emulsion were taken from the bottom of the beaker and dispersed into $5.0 \mathrm{~mL}$ of $0.1 \%$ (w/w) sodium dodecylsulfate (SDS) solution. After shaking in a vortex mixer, the absorbance of the diluted emulsions was measured at $500 \mathrm{~nm}$ against the $0.1 \%(\mathrm{w} / \mathrm{w})$ 
SDS solution. The emulsifying activity index (EAI) of FRBP was calculated using (2) as follows:

$$
\operatorname{EAI}\left(\mathrm{m}^{2} / \mathrm{g}\right)=\frac{2 \times 2.303 \times A_{0} \times \mathrm{DF}}{c \times(1-\varphi) \times 10000}
$$

where DF is the dilution factor (100); $c$ is the concentration of protein $(\mathrm{g} / \mathrm{mL}) ; \varphi$ is the fraction of oil used to form the emulsion; and $A_{0}$ is the absorbance of diluted emulsions.

2.2.5. Foaming Properties. A $1 \%(\mathrm{w} / \mathrm{v})$ FRBP solution was prepared. The $\mathrm{pH}$ of the protein solution was adjusted to 2, $3,4,4.5,5,6,7,8,9,10,11$, and 12 with either $0.1 \mathrm{M} \mathrm{HCl}$ or $0.1 \mathrm{M} \mathrm{NaOH}$. The solutions were stirred at $17,500 \mathrm{r} / \mathrm{min}$ or $2 \mathrm{~min}$. The blend was immediately transferred into a $100 \mathrm{~mL}$ graduated cylinder, and the volume was recorded before and after stirring. The foaming ability was calculated using (3) as follows:

$$
\text { Foaming ability }(\%)=\frac{\text { Volume after stirring }}{\text { Volume before stirring }} \times 100 \text {. }
$$

\subsubsection{Fat Absorption Capacity (FAC) and Water Absorption} Capacity (WAC). The FAC and WAC of FRBP were measured as previously described [15].

FAC Determination. The FRBP sample $(0.5 \mathrm{~g})$ was weighed into a $10 \mathrm{~mL}$ preweighed centrifuge tube and mixed with $3 \mathrm{~mL}$ of soybean oil. The emulsion was incubated at $30^{\circ} \mathrm{C}$ in a thermostat water bath for $30 \mathrm{~min}$ and then centrifuged at $1,000 \mathrm{r} / \mathrm{min}$ for $20 \mathrm{~min}$. The supernatant was then carefully removed, and the tube was reweighed.

WAC Determination. The FRBP sample $(2.0 \mathrm{~g})$ was weighed into a $10 \mathrm{~mL}$ preweighed centrifuge tube. Distilled water was added in small increments to the tube under continuous stirring with a glass rod until the mixture became a syrup and no water separation occurred. The tube was centrifuged at 2,500 $\mathrm{r} / \mathrm{min}$ for $10 \mathrm{~min}$. The supernatant was then removed, and the tube was weighed.

FAC or WAC was calculated using (4) as follows:

$$
\frac{\mathrm{FAC}}{\mathrm{WAC}(\mathrm{g} / \mathrm{g})}=\frac{\left(W_{0}+W_{1}\right)-\left(W_{0}+W_{2}\right)}{W_{2}},
$$

where $W_{0}$ is the weight of tube; $W_{1}$ is the weight of the pellet; and $W_{2}$ is the weight of FRBP.

2.2.7. Circular Dichroism (CD) Spectrum Analysis. CD spectrum analysis was performed according to the method of $\mathrm{Wu}$ et al. [16], which utilized a Far-UV CD spectropolarimeter (Jasco J-810, Jasco Corp., Tokyo, Japan) with a $0.1 \mathrm{~cm}$ quartz CD cuvette (Hellma, Muellheim, Baden, Germany) at $25 \pm 1^{\circ} \mathrm{C}$ to analyze the secondary structure of protein molecules. The measurement was conducted under the following conditions: scanning velocity of $100 \mathrm{~nm} / \mathrm{min}$; sensitivity of $100 \mathrm{medg} / \mathrm{cm}$; and scanning extension of 190-250 $\mathrm{nm}$.
2.2.8. Surface Hydrophobicity. The surface hydrophobicity was measured with the fluorescence probe, 1-aniline-8naphthalene sulfonate $\left(\mathrm{ANs}^{-}\right)$, according to the method of Jiang and Zhao [17]. The protein solution was excited at $390 \mathrm{~nm}$, and the emission fluorescence intensity (FI) was scanned at wavelengths from 400 to $600 \mathrm{~nm}$. The slit width for both excitation and emission was $5 \mathrm{~nm}$.

2.2.9. Intrinsic Fluorescence Spectroscopy. The intrinsic fluorescence spectroscopy was measured as previously described [17]. The FRBP sample was weighed and dissolved in $0.01 \mathrm{M}$ phosphate buffer at $\mathrm{pH} 7.0$ with magnetic stirring. The dispersion was then centrifuged at $4^{\circ} \mathrm{C}$ and $10,000 \times \mathrm{g}$ for $10 \mathrm{~min}$, and the protein concentration of the supernatant was then adjusted to $0.15 \mathrm{mg} / \mathrm{mL}$. The protein solution was excited at $290 \mathrm{~nm}$, and the emission spectrum was recorded from 300 to $400 \mathrm{~nm}$ at a constant slit of $5 \mathrm{~nm}$ for both excitation and emission.

2.2.10. Differential Scanning Calorimetry (DSC) Analysis. The denaturation of the FRBP products was evaluated based on DSC analysis according to the method of Haskard and LiChan [18]. The sample (2 mg) was accurately weighed into an aluminium liquid pan, and $10 \mu \mathrm{L}$ of $0.01 \mathrm{M}$ phosphate buffer ( $\mathrm{pH}$ 7.4) was added. The pan was hermetically sealed and held at $4^{\circ} \mathrm{C}$ overnight. The pan was heated from 30 to $120^{\circ} \mathrm{C}$ at a rate of $10^{\circ} \mathrm{C} / \mathrm{min}$ during which the pan was initially equilibrated at $30^{\circ} \mathrm{C}$ for $1 \mathrm{~min}$ and finally maintained at $120^{\circ} \mathrm{C}$ for $1 \mathrm{~min}$. A sealed empty pan was used as a reference. The denaturation temperature of protein $\left(T_{d}\right)$ and enthalpy change of the endotherm $(\ddot{\mathrm{A}} H)$ were computed from the thermograms.

2.2.11. Statistical Analysis. All data were expressed as the means \pm standard deviation from at least three independent experiments. Differences between the mean values of multiple groups were analyzed by one-way analysis of variance (ANOVA) with Duncan's multiple range tests. MS Excel 2003 was used to analyze and report the data.

\section{Results and Discussion}

3.1. Effect of Extraction Method on the Yield of FRBP. The yields of FRBP products prepared by the two extraction methods were compared and are shown in Table 1 . The yields of the FRBP products were 12.7 and $13.8 \mathrm{~g}$ with methods 1 and 2, respectively, which were consistent with previous studies [19]. Albumin, globulin, and glutelin were the major FRBP products prepared by the two extraction methods, and prolamin only comprised $1-3 \%$ of the total yield of FRBP products. Method 2 resulted in albumin forming a white flocculation precipitate, which was different from the pale yellowish albumin precipitate obtained through method 1 . Comparison of the two extraction methods showed that the total yield of FRBP products was significantly different $(P<$ 0.05). Method 2 resulted in a higher total yield of FRBP products and a larger proportion of prolamin. There was low concentration of prolamin filtrate extracted through method 
TABLE 1: Effect of extraction methods on the yield of FRBP $(n=3)^{\mathrm{a}}$.

\begin{tabular}{|c|c|c|c|c|}
\hline \multirow{2}{*}{ FRBP } & \multicolumn{2}{|l|}{ Method 1} & \multicolumn{2}{|l|}{ Method 2} \\
\hline & Yield (g/100 g defatted rice bran) & Ratio (\%) & Yield (g/100 g defatted rice bran) & Ratio (\%) \\
\hline Albumin & $5.1 \pm 0.20^{\mathrm{a}}$ & $40.2 \pm 0.1$ & $3.2 \pm 0.35^{\mathrm{b}}$ & $23.5 \pm 1.2$ \\
\hline Globulin & $3.2 \pm 0.23^{\mathrm{a}}$ & $25.2 \pm 0.2$ & $4.8 \pm 0.67^{\mathrm{b}}$ & $35.3 \pm 1.4$ \\
\hline Prolamin & $0.086 \pm 0.001^{\mathrm{a}}$ & $0.6 \pm 0.03$ & $0.6 \pm 0.06^{\mathrm{b}}$ & $2.9 \pm 0.6$ \\
\hline Glutelin & $4.5 \pm 0.26^{\mathrm{a}}$ & $33.8 \pm 1.4$ & $5.1 \pm 0.2^{\mathrm{b}}$ & $38.2 \pm 1.8$ \\
\hline Total yield & $12.9 \pm 0.21^{\mathrm{a}}$ & & $13.7 \pm 0.42^{\mathrm{b}}$ & \\
\hline
\end{tabular}

${ }^{a}$ The different superscript letter in the same line represents the fact that they are significantly different $(P<0.05)$.

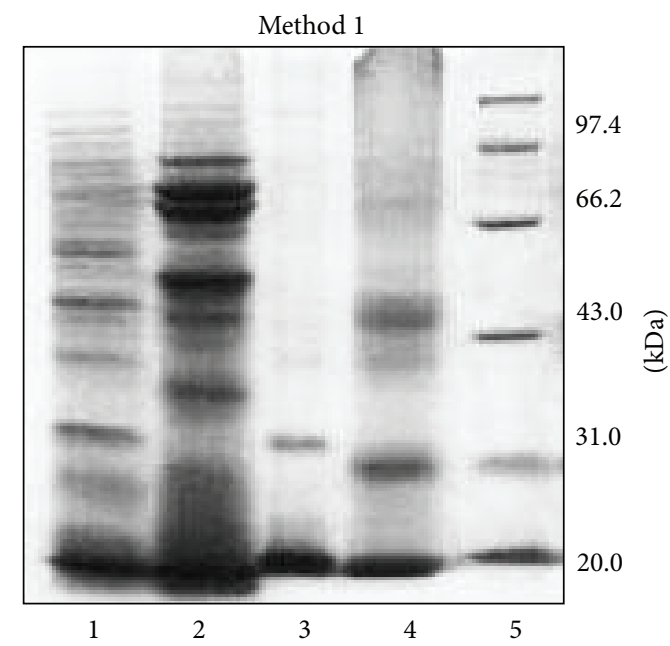

(a)

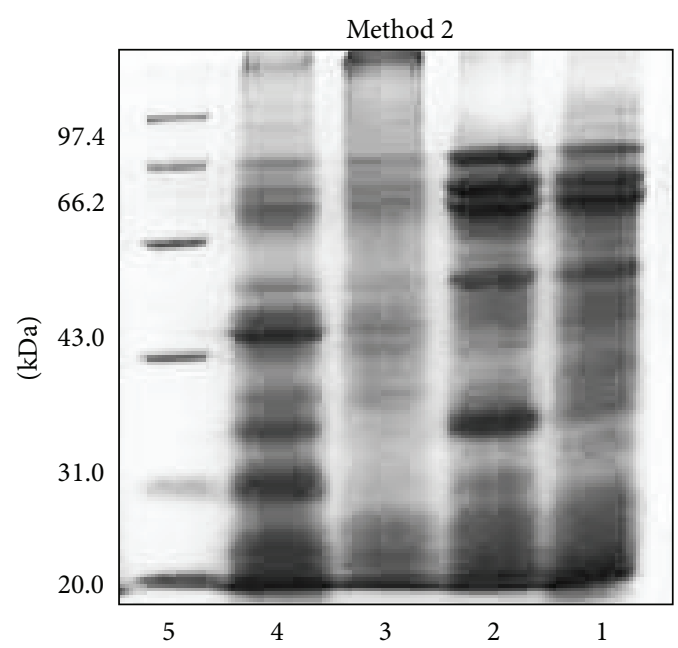

(b)

FIGURE 1: SDS-PAGE pattern of FRBP obtained by the two extraction methods. Lanes 1-5: albumin, globulin, prolamin, glutelin, and marker, respectively.

1, which made prolamin difficult to precipitate when acetone was added. Moreover, the rotary evaporation combined with hexane extraction in method 2 was used to prepare defatted prolamin concentrate. Thus, the prolamin yield and purity resulting from method 2 were higher than those resulting from method 1 . The ratios of the albumin, globulin, glutelin, and prolamin fractions slightly varied with the extraction methods in this study, which may have been due to the different extraction solvents used. Method 2 was better than method 1 in its efficiency and ease of manipulation. Based on method 2, the total yield of FRBP products was $13.8 \%$, and the purity ranged from 45 to $78 \%$.

3.2. SDS-PAGE Patterns of FRBP. The protein patterns extracted by each method were analyzed by SDS-PAGE (Figure 1). Both albumin and globulin prepared by method 1 showed similar protein patterns in the 63 and $21 \mathrm{kDa}$ regions indicating their cross-contamination. In contrast, differences in the protein patterns were observed between albumin and globulin prepared by method 2 with the following molecular mass distributions of subunits: $32,31,22,17$, and $14 \mathrm{kDa}$ for albumin and $63,53,49,36$, and $22 \mathrm{kDa}$ for globulin. These results indicated that albumin and globulin were better separated by salt precipitation. Four major subunits with molecular masses of $63,53,49,36$, and $22 \mathrm{kDa}$ comprised the glutelin fraction prepared by method 2. In addition to the four abovementioned subunits, additional bands were observed in the protein patterns of the glutelin fraction prepared by method 1 . Thus, glutelin was not well separated through method 2 indicating that the pretreatment negatively affected the extraction of glutelin. The alkaline extraction combined with a water wash in method 2 prevented the cross-contamination among albumin, globulin, and glutelin, thus resulting in clearer protein bands. A similar difference occurred between the subunits of prolamin prepared through the two extraction methods. In particular, the 13 and $22 \mathrm{kDa}$ bands of prolamin prepared by method 2 were darker than those resulting from method 1, which suggested that the purity of the prolamin fraction was higher in method 2, which correlated with the Kjeldahl determination results. Compared with previous studies [19], method 2 was found to be a better extraction method for fractionating rice bran proteins.

3.3. Solubility of Protein. The solubility of FRBP products prepared by the two extraction methods was determined at different $\mathrm{pH}$ levels and is shown in Figure 2. In general, the solubility curves of the four FRBP products were shaped like a "v". The solubility of the FRBP products prepared by method 1 was lower than that prepared by method 2 at $\mathrm{pH}$ 


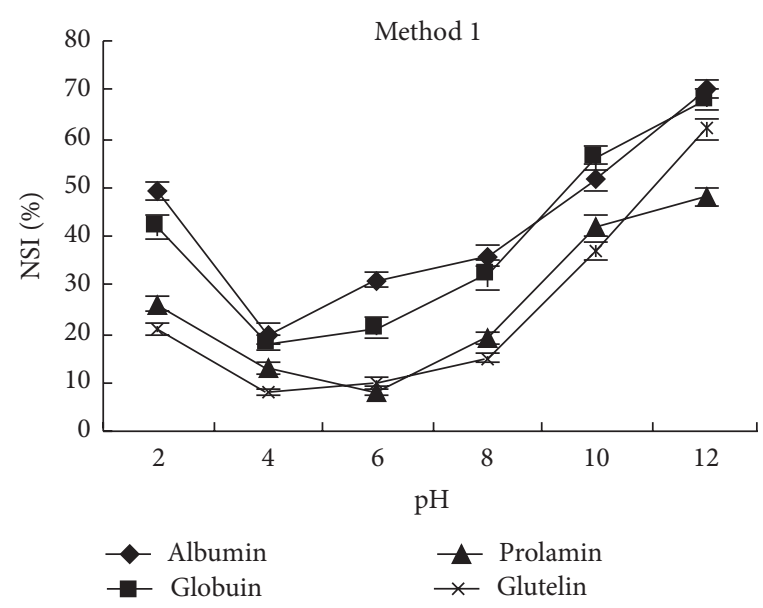

(a)

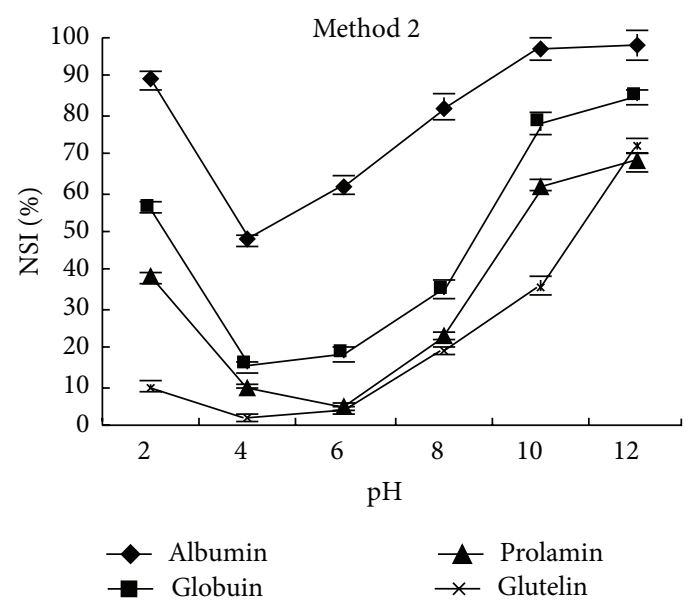

(b)

FIGURE 2: Protein solubility at different $\mathrm{pH}$ levels of FRBPs prepared by the two extraction methods.

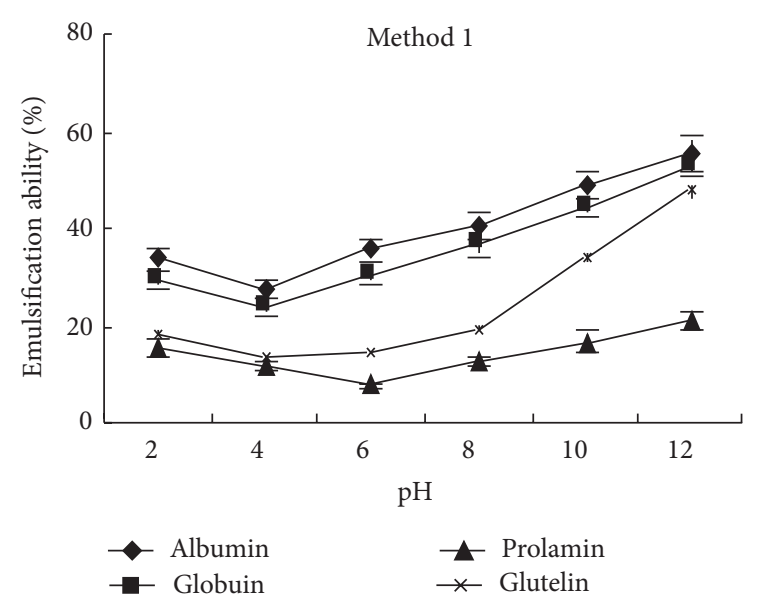

(a)

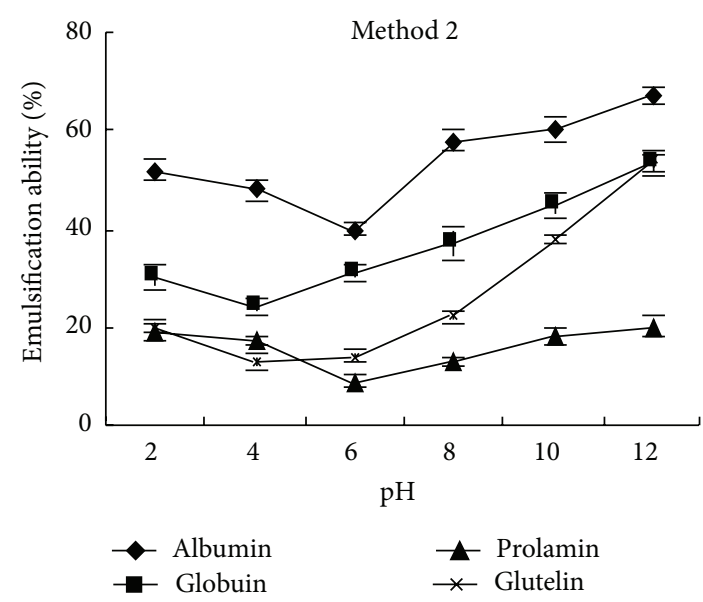

(b)

FIgURE 3: Emulsion activity index at different pH levels of FRBPs prepared by the two extraction methods.

from 2 to 12. Figure 2(b) shows that the solubility of albumin at $\mathrm{pH} 12$ was nearly $100 \%$, but Figure 2(a) shows that the solubility of albumin was $70 \%$. Protein solubility is a fundamental property that determines the application of FRBP. In food processing, the application area of protein could be significantly increased if the protein exhibits good solubility in different conditions. Thus, FRBP products obtained by method 2 were considered to be better materials for food processing.

3.4. Emulsion Properties. The emulsion properties of FRBP products prepared by the two extraction methods are shown in Figure 3. All of the EAI data of FRBP products changed with the variation of $\mathrm{pH}$ levels. The EAI values of the four FRBP products were increased when the $\mathrm{pH}$ was changed from 6 to 12. The emulsion activities of FRBP products prepared by method 2 were higher than those prepared by method 1, especially for albumin. These results suggested that the solubility of albumin extracted by method 2 was better, which was in accordance with the results above.

3.5. Foaming Properties. The foaming properties at different $\mathrm{pH}$ levels of FRBP products are shown in Figure 4. The foaming property changed with the variation of $\mathrm{pH}$. The foaming property of FRBP products prepared by method 2 was slightly higher than that of FRBP products prepared by method 1. It has been reported that the foaming property and stability of protein are positively related to its solubility and that the foaming property is also decided by the flexibility of the protein molecule [20].

Previous studies have revealed that the surface hydrophobic groups of protein normally tend to be distributed around the oil/water or liquid/air interface of the emulsion and that the hydrophilic groups are exposed to the water phase. The 


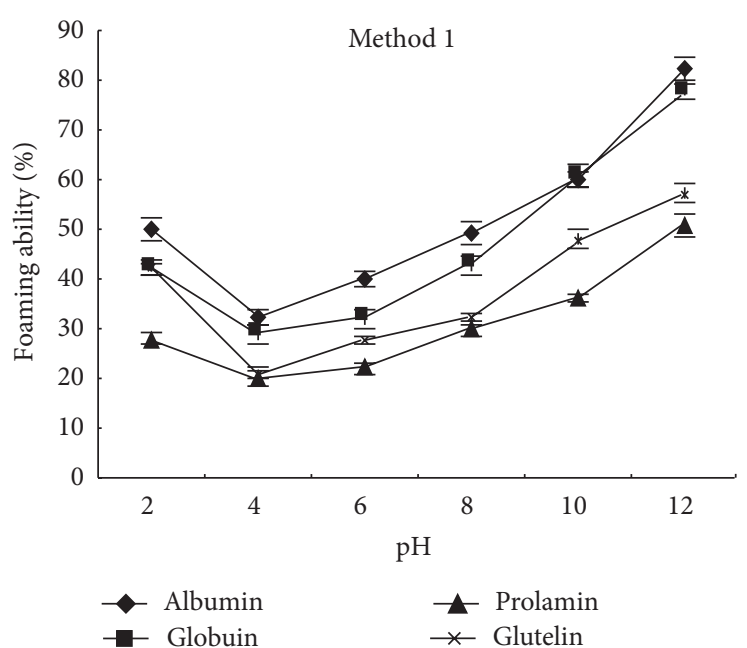

(a)

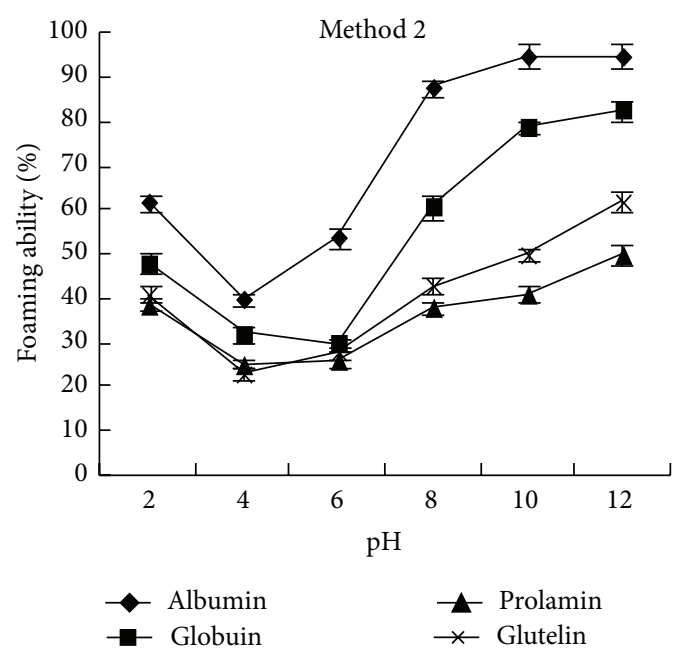

(b)

FIGURE 4: Foam properties at different $\mathrm{pH}$ levels of FRBPs prepared by the two extraction methods.

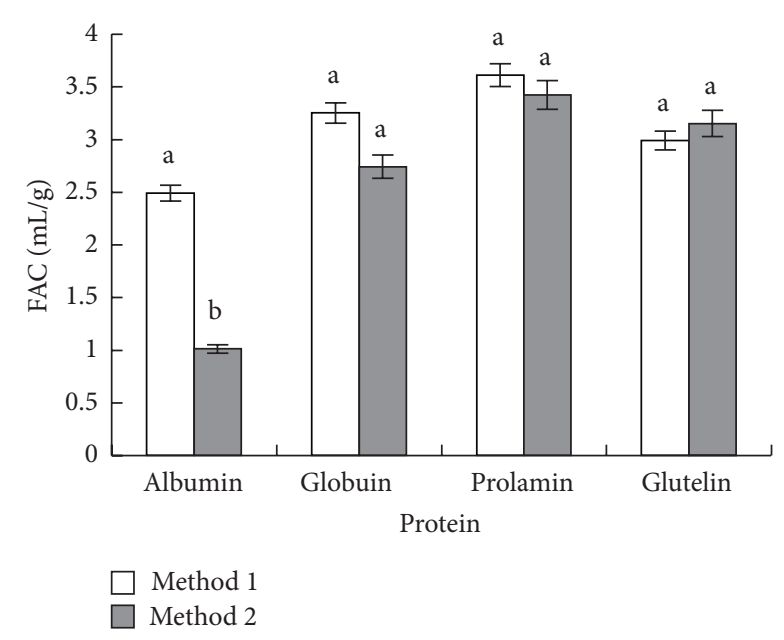

FIGURE 5: FAC of FRBPs prepared by the two extraction methods.

saccharide-protein complex is capable of forming a stable emulsion and foam because the side chain of the saccharideprotein complex improves the surface hydrophobicity of the protein molecule resulting in an increased interaction between the protein and water molecules. Thus, the apparent viscosity of the protein dispersion and the stability of the foam and emulsion are increased [21].

3.6. FAC and WAC. The FAC and WAC values of the four FRBP products are shown in Figures 5 and 6, respectively. There was a significant difference between the FAC values of albumin prepared by method 1 and by method 2. The fat absorption capacity is one of the fundamental characteristics of protein, which enables protein to be used as a meat substitute or extender for flavor retention and taste improvement [22]. In this study, the FRBP products obtained by method 1 showed higher FAC values exhibiting its potential use as

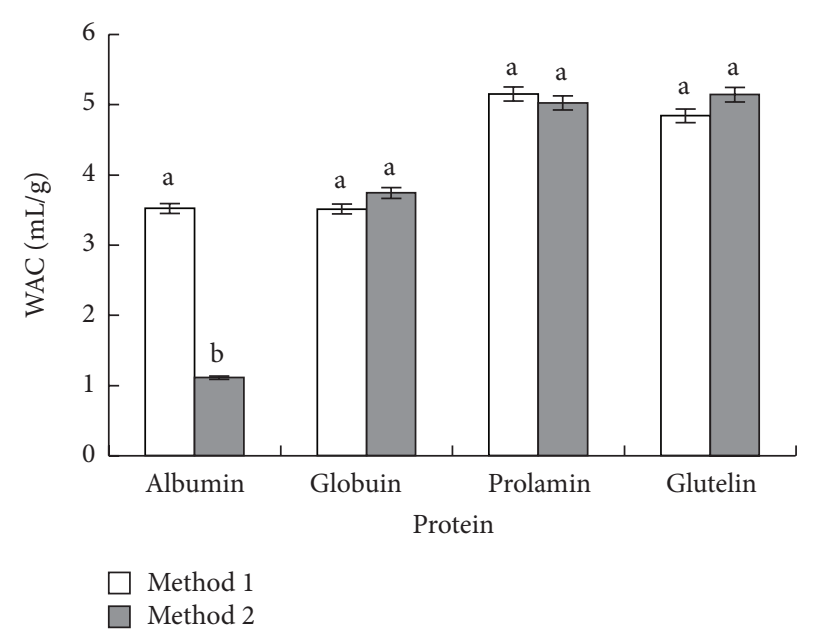

FIGURE 6: WAC of FRBPs prepared by the two extraction methods.

food ingredients in the cold meat industry, particularly for sausages, where the protein is usually associated with fat and water to obtain good products.

The WAC value of albumin prepared by method 2 was higher than that of method 1 , but the WAC values of prolamin resulting from the two extraction methods had the opposite trend (Figure 6). These results indicated that the solubility of protein was not directly correlated with its WAC, which agreed with the results of a previous study [23]. The water absorption capacity of protein is decided by several interactive factors as follows: size, shape, steric characteristics, conformational characteristics, and the hydrophilichydrophobic balance of amino acids in the protein molecules. Thus, the FRBP products containing albumin, prolamin, and glutelin with high WAC values obtained by method 2 could be applied in the food industry for some products, such as meat, bread, and cakes. 
TABLE 2: Surface hydrophobicity $\left(H_{0}\right)$ of FRBPs prepared by the two extraction methods ${ }^{\mathrm{a}}$.

\begin{tabular}{|c|c|c|c|c|c|c|c|c|}
\hline & \multicolumn{4}{|c|}{ Method 1} & \multicolumn{4}{|c|}{ Method 2} \\
\hline & $\begin{array}{l}\text { Albumin } \\
\text { prepared by } \\
\text { method } 1\end{array}$ & $\begin{array}{l}\text { Globulin } \\
\text { prepared by } \\
\text { method } 1\end{array}$ & $\begin{array}{l}\text { Prolamin } \\
\text { prepared by } \\
\text { method } 1\end{array}$ & $\begin{array}{l}\text { Glutelin } \\
\text { prepared by } \\
\text { method } 1\end{array}$ & $\begin{array}{l}\text { Albumin } \\
\text { prepared by } \\
\text { method } 2\end{array}$ & $\begin{array}{l}\text { Globulin } \\
\text { prepared by } \\
\text { method } 2\end{array}$ & $\begin{array}{l}\text { Prolamin } \\
\text { prepared by } \\
\text { method } 2\end{array}$ & $\begin{array}{l}\text { Glutelin } \\
\text { prepared by } \\
\text { method } 2\end{array}$ \\
\hline$H_{0}$ & $560 \pm 26.6^{\mathrm{a}}$ & $1187 \pm 67.5^{\mathrm{a}}$ & $362 \pm 11.1^{\mathrm{a}}$ & $695 \pm 7.5^{\mathrm{a}}$ & $833 \pm 25.7^{\mathrm{b}}$ & $960 \pm 61.1^{b}$ & $338 \pm 14.5^{\mathrm{a}}$ & $681 \pm 33.2^{\mathrm{a}}$ \\
\hline
\end{tabular}

${ }^{\mathrm{a}}$ The different superscript letter in the same line represents the fact that they are significantly different $(P<0.05)$.

TABLE 3: Parameters of the intrinsic emission fluorescence spectra of FRBPs prepared by the two extraction methods.

\begin{tabular}{|c|c|c|c|c|c|c|c|c|}
\hline & \multicolumn{4}{|c|}{ Method 1} & \multicolumn{4}{|c|}{ Method 2} \\
\hline & Albumin & Globulin & Prolamin & Glutelin & Albumin & Globulin & Prolamin & Glutelin \\
\hline $\begin{array}{l}\text { Fluorescence } \\
\text { emission } \\
\text { maximum }\left(\lambda_{m}\right)\end{array}$ & $335.00 \pm 0.75^{\mathrm{a}}$ & $335.25 \pm 1.00^{\mathrm{a}}$ & $342.50 \pm 2.65^{\mathrm{a}}$ & $344.00 \pm 2.00^{\mathrm{a}}$ & $337.00 \pm 0.06^{\mathrm{b}}$ & $341.25 \pm 1.74^{\mathrm{b}}$ & $341.00 \pm 0.58^{\mathrm{a}}$ & $339.00 \pm 1.00^{\mathrm{a}}$ \\
\hline $\begin{array}{l}\text { The } \\
\text { fluorescence } \\
\text { intensity at } \lambda_{m}\end{array}$ & $300.11 \pm 5.20^{\mathrm{a}}$ & $341.22 \pm 5.57^{\mathrm{a}}$ & $98.25 \pm 6.00^{\mathrm{a}}$ & $151.31 \pm 7.22^{\mathrm{a}}$ & $576.24 \pm 10.44^{b}$ & $633.21 \pm 6.25^{\mathrm{b}}$ & $199.13 \pm 5.57^{b}$ & $200.14 \pm 4.59^{b}$ \\
\hline
\end{tabular}

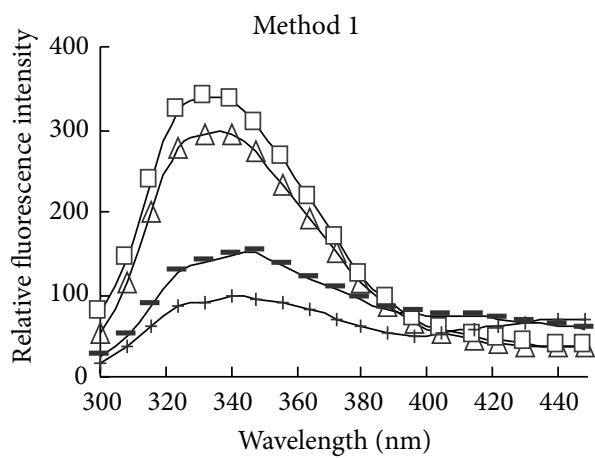

$\begin{array}{ll}\triangle \text { Albumin } & \quad \text { Prolamin } \\ -\square-\text { Globulin } & - \text { Glutelin }\end{array}$

(a)

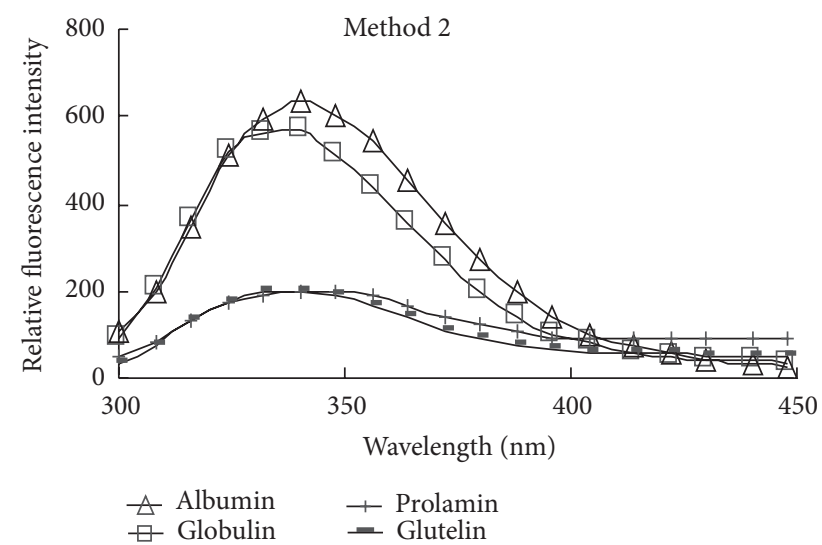

(b)

FIGURE 7: Intrinsic emission fluorescence spectra of FRBPs prepared by the two extraction methods.

3.7. Surface Hydrophobicity $\left(H_{0}\right)$ Analysis. The surface hydrophobicity the FRBP products obtained by method 1 and method 2 was analyzed (Table 2). The surface hydrophobicity values of the four FRBP products obtained by method 2 were higher than that of method 1 in varying degrees. Considering the results of either method 1 or method 2, the $H_{0}$ values of the FRBP products were higher than the values previously reported for other proteins, such as soy protein isolate (206.76) [24]. Proteins with high $H_{0}$ values generally exhibit high foaming capacity, which is needed for specific food product applications [25].

3.8. Intrinsic Fluorescence Spectroscopy Analysis. To analyze the difference of tertiary structures of the FRBP products obtained by the two extraction methods, the intrinsic fluorescence spectra of the proteins were investigated (Figure 7). These spectra were characteristic of the fluorescence profile of tryptophan residues. The fluorescence emission maximum $\left(\lambda_{m}\right)$ values of albumin, globulin, prolamin, and glutelin obtained by method 1 were $335,335,342$, and $344 \mathrm{~nm}$, respectively. However, the fluorescence emission maximum $\left(\lambda_{m}\right)$ values of albumin, globulin, prolamin, and glutelin obtained by method 2 were 337, 341, 341, and $339 \mathrm{~nm}$, respectively, as shown in Table 3. Compared with those of method 1, the FRBP products extracted through method 2 led to a blue shift of $\lambda_{m}$ indicating that the chromophores became less exposed to solvent.

3.9. DSC Analysis of FRBP Product Denaturation. The DSC analysis of FRBP product denaturation was also performed. In the DSC spectrum, the denaturation temperature $\left(T_{d}\right)$ represents the thermal stability of the protein, and the enthalpy change of the endotherm $(\Delta H)$ indicates the hydrophilic/hydrophobic characteristics of the protein, which could lead to protein aggregation. The denaturation characteristics of the FRBP products prepared by the two 
TABLE 4: DSC analysis on the denaturation of FRBPs prepared by the two extraction methods.

\begin{tabular}{|c|c|c|c|c|c|c|c|c|}
\hline & \multicolumn{4}{|c|}{ Method 1} & \multicolumn{4}{|c|}{ Method 2} \\
\hline & Albumin & Globulin & Prolamin & Glutelin & Albumin & Globulin & Prolamin & Glutelin \\
\hline$\overline{T_{d}\left({ }^{\circ} \mathrm{C}\right)}$ & $88.26 \pm 1.67^{\mathrm{a}}$ & $91.34 \pm 2.31^{\mathrm{a}}$ & $87.06 \pm 4.24^{\mathrm{a}}$ & $79.04 \pm 1.05^{\mathrm{a}}$ & $77.14 \pm 5.02^{b}$ & $92.88 \pm 1.55^{\mathrm{a}}$ & $87.97 \pm 1.11$ & $78.58 \pm 1.38^{\mathrm{a}}$ \\
\hline$\Delta H(\mathrm{~J} / \mathrm{g})$ & $1.68 \pm 0.09^{\mathrm{a}}$ & $2.89 \pm 0.14^{\mathrm{a}}$ & $4.08 \pm 0.14^{\mathrm{a}}$ & $6.90 \pm 0.16^{\mathrm{a}}$ & $2.20 \pm 0.10^{\mathrm{b}}$ & $2.41 \pm 0.28^{\mathrm{b}}$ & $6.26 \pm 0.21^{b}$ & $7.31 \pm 0.26^{\mathrm{a}}$ \\
\hline
\end{tabular}

${ }^{\mathrm{a}, \mathrm{b}}$ The different superscript letter in the same protein with two different extraction represents the fact that they are significantly different.

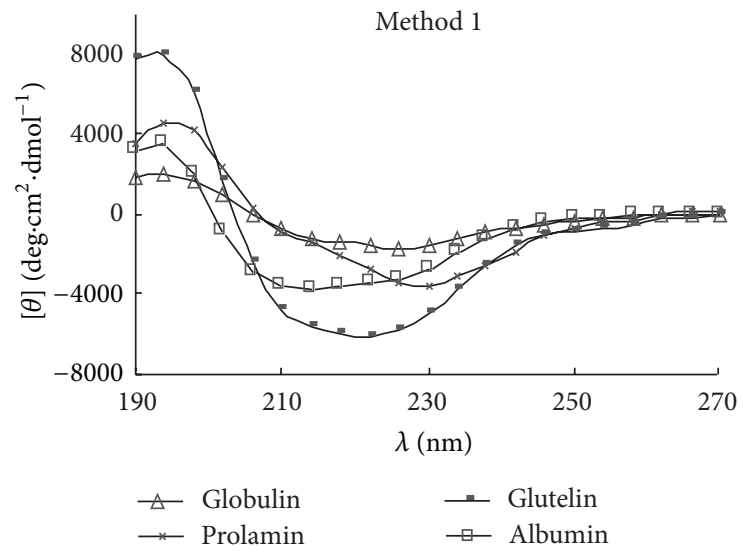

(a)

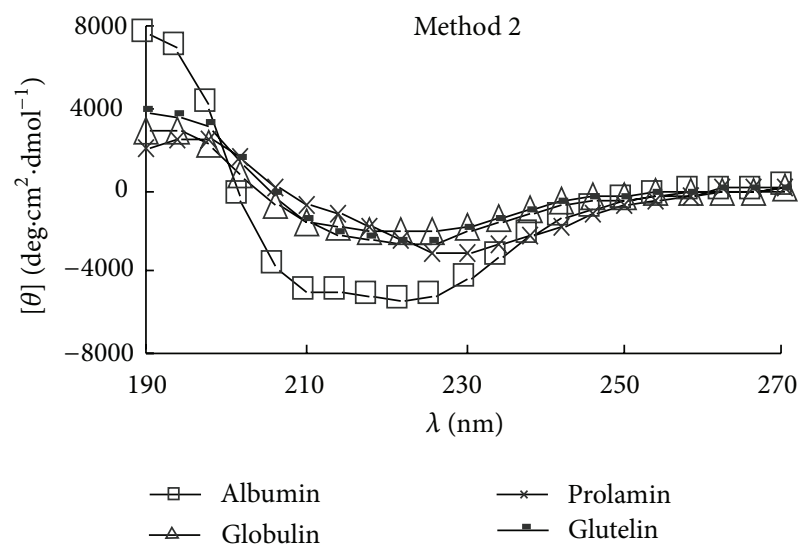

(b)

FIGURE 8: CD spectra of FRBPs prepared by the two extraction methods.

extraction methods are shown in Table 4. There were no significant differences $(P<0.05)$ in $T_{d}$ values between the two methods, except for albumin, which was $88.26^{\circ} \mathrm{C}$ for method 1 and $80.47^{\circ} \mathrm{C}$ for method 2. This difference may be attributed to the existence of disulfide bonds and hydrosulfide groups in the protein molecules. The thermal stability of proteins has been reported to involve a large number of disulfide bonds [26]. Our results were consistent with previous studies as glutelin, which contained the largest composition of sulfur-containing amino acids, exhibited the lowest $T_{d}$.

3.10. Circular Dichroism Spectra Analysis. CD spectra are remarkably sensitive to the secondary structures of proteins. The Far-UV CD spectra of the FRBP products prepared by the two extraction methods are shown in Figure 8. The Far-UV CD spectra of the FRBP products extracted by method 1 were slightly different from those of method 2. Albumin prepared by method 1 and method 2 exhibited the largest variation in the Far-UV spectra. The secondary structure of albumin prepared by method 1 was calculated to comprise $8.1 \% \alpha$ helix, $38.7 \% \beta$-sheet, $22.3 \% \beta$-turn, and 30.8\% random coil. Albumin prepared by method 2 was calculated to comprise $19.2 \% \alpha$-helix, $34.7 \% \beta$-sheet, $23.1 \% \beta$-turn, and $28 \%$ random coil. These results suggested that method 1 led to a larger variety of secondary structures of albumin, including the loss of $\alpha$-helix structures and the formation of $\beta$-sheet and random coil structures. Thus, the extraction solvents used in method 1 had detrimental effects on the folded structure of albumin.

\section{Conclusion}

In this work, the solubility, emulsion activity, foaming property, FAC, and WAC of the four FRBP products extracted by the two extraction methods were studied, and the structural changes of protein were further analyzed based on the results of CD spectra, surface hydrophobicity, intrinsic fluorescence spectra, and DSC spectra. The results indicated that albumin, globulin, prolamin, and glutelin prepared by method 2 had better properties than those of method 1 . Thus, we concluded that method 2 is the optimum method for the extraction of FRBP products from defatted rice bran.
Abbreviations
FRBP: $\quad$ Fractionated rice bran protein
SDS-PAGE: Sodium dodecyl sulfate polyacrylamide gel electrophoresis
CD spectrum: Circular dichroism spectrum
DSC: Differential scanning calorimetry
EAI: $\quad$ Emulsifying activity index
NSI: Nitrogen solubility index
FAC: $\quad$ Fat absorption capacity
WAC: Water absorption capacity.

\section{Ethical Approval}

This paper does not contain any studies with human or animal subjects. 


\section{Conflict of Interests}

The authors declare that there is no conflict of interests regarding the publication of this paper.

\section{Authors' Contributions}

During the development of this project, the authors benefited from suggestions and critical insights provided by Wang Changyuan and Zhangmin. Valuable comments on a first draft were received from Xu Feng and Hao Tianshu. Li Dan provided valuable comments on a later draft and on the index.

\section{Acknowledgments}

The authors acknowledge financial support from the National Natural Science Funding Project (31101387, 31371830, and 31171657) and the "Twelfth Five-Year" National Science and Technology Support Project (2012BAD34B00). The authors would also like acknowledge the funding from the Heilongjiang Department of Education Scientific Research Project (12531446).

\section{References}

[1] A. W. Burks and R. M. Helm, "Hypoallerginicity of rice protein," in Proceedings of the Annual Meeting of the American Association of Cereal Chemists, Nashville, Tenn, USA, 1994.

[2] M. Wang, N. S. Hettiarachchy, M. Qi, W. Burks, and T. Siebenmorgen, "Preparation and functional properties of rice bran protein isolate," Journal of Agricultural and Food Chemistry, vol. 47, no. 2, pp. 411-416, 1999.

[3] S. Gorinstein, E. Pawelzik, E. Delgado-Licon, R. Haruenkit, M. Weisz, and S. Trakhtenberg, "Characterisation of pseudocereal and cereal proteins by protein and amino acid analyses," Journal of the Science of Food and Agriculture, vol. 82, no. 8, pp. 886-891, 2002.

[4] A. Rangel, G. B. Domont, C. Pedrosa, and S. T. Ferreira, "Functional properties of purified vicilins from cowpea (Vigna unguiculata) and pea (Pisum sativum) and cowpea protein isolate," Journal of Agricultural and Food Chemistry, vol. 51, no. 19, pp. 5792-5797, 2003.

[5] D. S. Sogi, S. K. Garg, and A. S. Bawa, "Functional properties of seed meals and protein concentrates from tomato-processing waste," Journal of Food Science, vol. 67, no. 8, pp. 2997-3001, 2002.

[6] H. Tomotake, I. Shimaoka, J. Kayashita, M. Nakajoh, and N. Kato, "Physicochemical and functional properties of buckwheat protein product," Journal of Agricultural and Food Chemistry, vol. 50, no. 7, pp. 2125-2129, 2002.

[7] J. S. Hamada, "Characterization and functional properties of rice bran proteins modified by commercial exoproteases and endoproteases," Journal of Food Science, vol. 65, no. 2, pp. 305310,2000

[8] S. Tang, N. S. Hettiarachchy, R. Horax, and S. Eswaranandam, "Physicochemical properties and functionality of rice bran protein hydrolyzate prepared from heat-stabilized defatted rice bran with the aid of enzymes," Journal of Food Science, vol. 68, no. 1, pp. 152-157, 2003.
[9] M. V. Grossman, C. S. Rao, and R. S. F. da Silva, "Extraction of protein from buckwheat bran: application of enzymes," Journal of Food Biochemistry, vol. 4, pp. 181-184, 1980.

[10] K. Tsutsumi, Y. Kawauchi, Y. Kondo, Y. Inoue, O. Koshitani, and H. Kohri, "Water extract of defatted rice bran suppresses visceral fat accumulation in rats," Journal of Agricultural and Food Chemistry, vol. 48, no. 5, pp. 1653-1656, 2000.

[11] R. Gnanasambandam and N. S. Heitiarachchy, "Protein concentrates from unstabilized and stabilized rice bran: preparation and properties," Journal of Food Science, vol. 60, no. 5, pp. 10661069, 1995.

[12] A. A. Betschart, R. Y. Fong, and R. M. Saunders, "Rice byproducts: comparative extraction and precipitation of nitrogen from us and Spanish bran and germ," Journal of Food Science, vol. 42, no. 4, pp. 1088-1093, 1977.

[13] U. K. Laemmli, "Cleavage of structural proteins during the assembly of the head of bacteriophage T4," Nature, vol. 227, no. 5259, pp. 680-685, 1970.

[14] O. H. Lowry, N. J. Rosebrough, A. L. Farr, and R. J. Randall, "Protein measurement with the Folin Phenol reagent," The Journal of biological chemistry, vol. 193, no. 1, pp. 265-275, 1951.

[15] L. R. Beuchat, "Functional and electrophoretic characteristics of succinylated peanut flour protein," Journal of Agricultural and Food Chemistry, vol. 25, no. 2, pp. 258-261, 1977.

[16] W. Wu, C. Zhang, X. Kong, and Y. Hua, "Oxidative modification of soy protein by peroxyl radicals," Food Chemistry, vol. 116, no. 1, pp. 295-301, 2009.

[17] S.-J. Jiang and X.-H. Zhao, "Transglutaminase-induced crosslinking and glucosamine conjugation in soybean protein isolates and its impacts on some functional properties of the products," European Food Research and Technology, vol. 231, no. 5, pp. 679-689, 2010.

[18] C. A. Haskard and E. C. Y. Li-Chan, "Hydrophobicity of bovine serum albumin and ovalbumin determined using uncharged (PRODAN) and anionic (ANS ${ }^{-}$) fluorescent probes," Journal of Agricultural and Food Chemistry, vol. 46, no. 7, pp. 2671-2677, 1998.

[19] A. P. Adebiyi, A. O. Adebiyi, Y. Hasegawa, T. Ogawa, and K. Muramoto, "Isolation and characterization of protein fractions from deoiled rice bran," European Food Research and Technology, vol. 228, no. 3, pp. 391-401, 2009.

[20] D. E. Graham and M. C. Phillips, "Proteins at liquid interfaces. I. Kinetics of adsorption and surface denaturation," Journal of Colloid And Interface Science, vol. 70, no. 3, pp. 403-414, 1979.

[21] A. B. Hassan, G. A. Osman, and E. E. Babiker, "Effect of chymotrypsin digestion followed by polysaccharide conjugation or transglutaminase treatment on functional properties of millet proteins," Food Chemistry, vol. 102, no. 1, pp. 257-262, 2007.

[22] S. O. Ogunwolu, F. O. Henshaw, H.-P. Mock, A. Santros, and S. O. Awonorin, "Functional properties of protein concentrates and isolates produced from cashew (Anacardium occidentale L.) nut," Food Chemistry, vol. 115, no. 3, pp. 852-858, 2009.

[23] W. Prinyawiwatkul, L. R. Beuchat, K. H. McWatters, and R. D. Phillips, "Functional properties of cowpea (Vigna unguiculata) flour as affected by soaking, boiling, and fungal fermentation," Journal of Agricultural and Food Chemistry, vol. 45, no. 2, pp. 480-486, 1997.

[24] K. X. Zhu, X. H. Sun, Z. C. Chen, W. Peng, H. F. Qian, and H. M. Zhou, "Comparison of functional properties and secondary structures of defatted wheat germ proteins separated by reverse micelles and alkaline extraction and isoelectric precipitation," Food Chemistry, vol. 123, no. 4, pp. 1163-1169, 2010. 
[25] A. Mohamed, S. C. Peterson, M. P. Hojilla-Evangelista, D. J. Sessa, P. Rayas-Duarte, and G. Biresaw, "Effect of heat treatment and $\mathrm{pH}$ on the thermal, surface, and rheological properties of Lupinus albus protein," Journal of the American Oil Chemists' Society, vol. 82, no. 2, pp. 135-140, 2005.

[26] J. E. Kinsella, "Relationship between structure and functional properties of food proteins," in Food Proteins, P. F. Fox and J. J. Cowden, Eds., pp. 51-103, Applied Science Publisher, London, UK, 1982. 

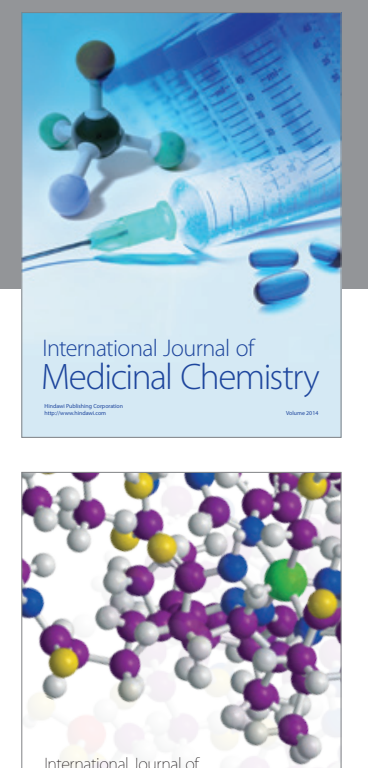

\section{Carbohydrate} Chemistry

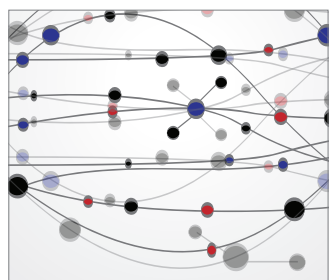

The Scientific World Journal
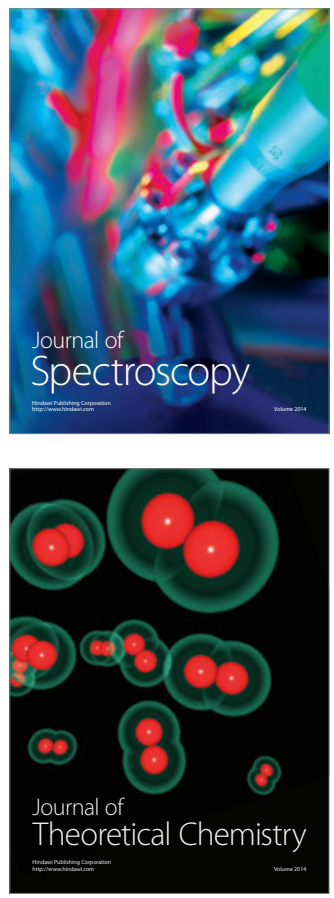
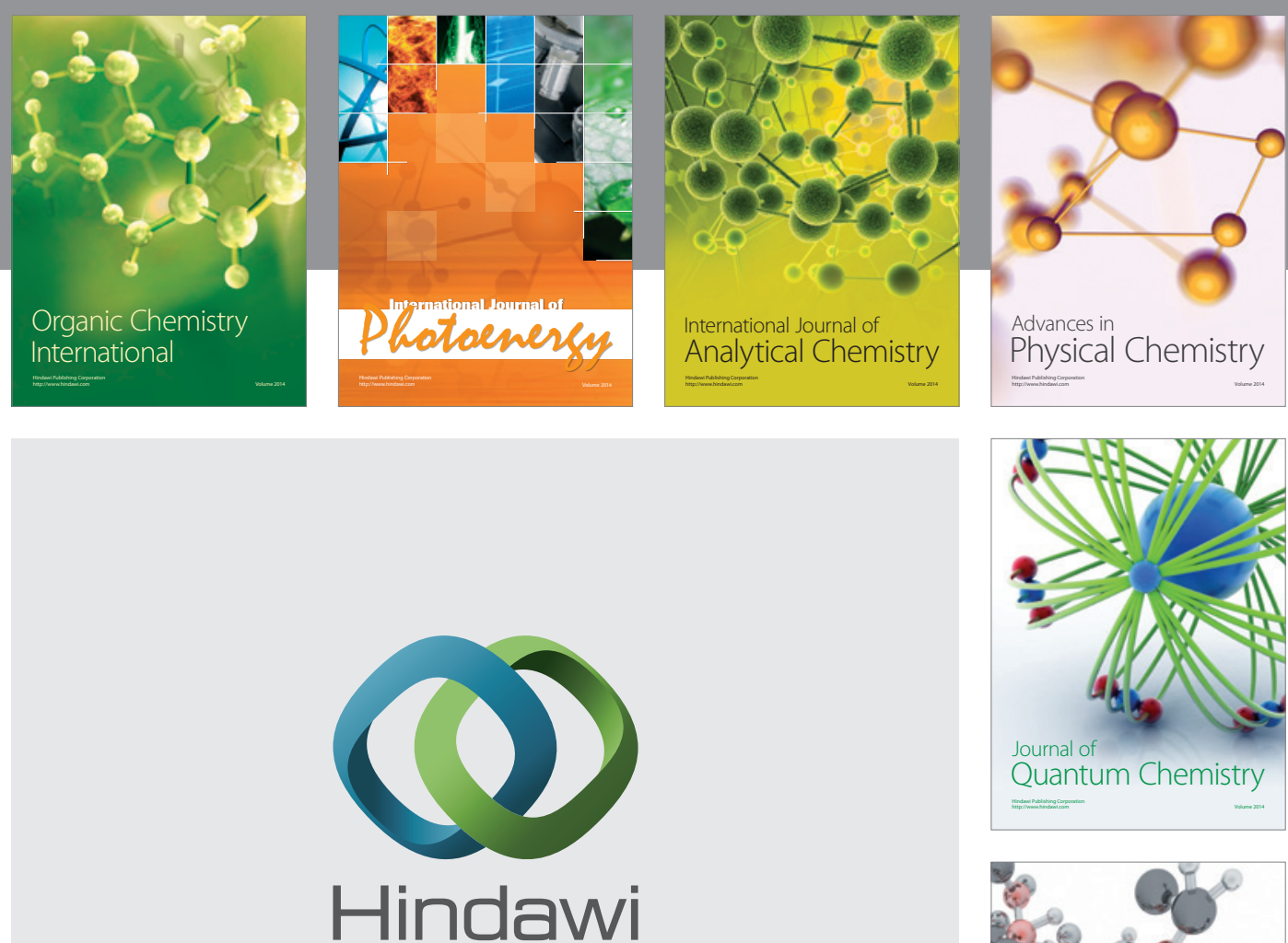

Submit your manuscripts at

http://www.hindawi.com

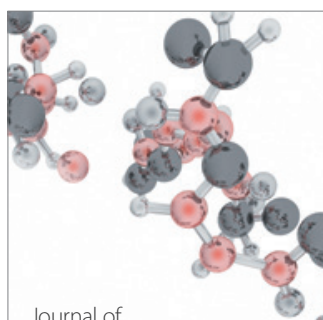

Analytical Methods

in Chemistry

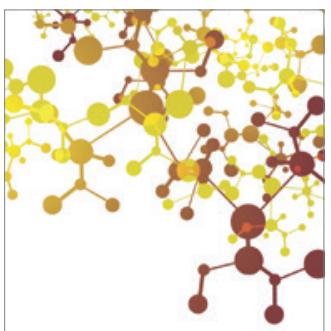

Journal of

Applied Chemistry

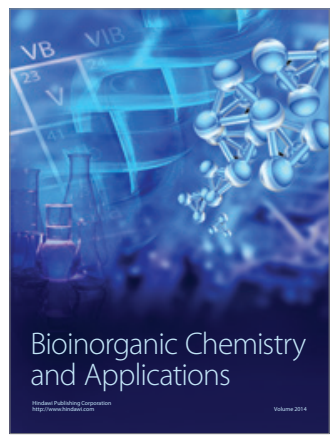

Inorganic Chemistry
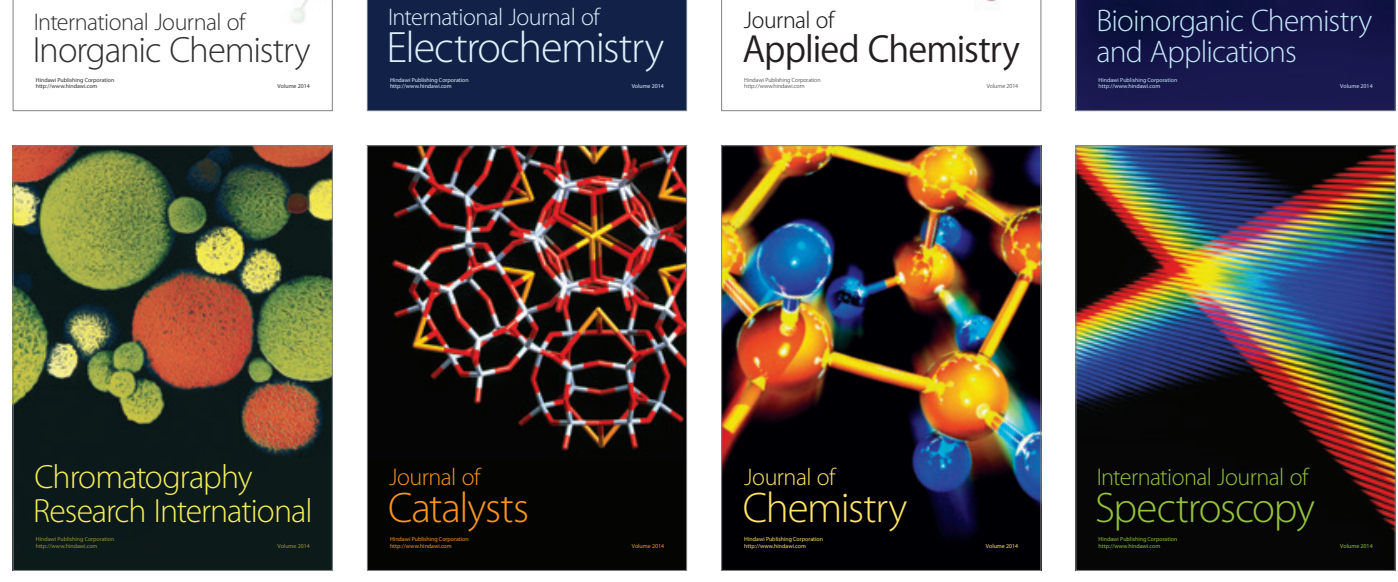